\title{
Aligning conservation and research priorities for proactive species and habitat management: the case of dugongs Dugong dugon in Johor, Malaysia
}

\author{
Louisa S. Ponnampalam, J. H. Fairul Izmal, Kanjana Adulyanukosol \\ Jillian L. S. OOI and John E. REYNOLDS III
}

\begin{abstract}
Conservation efforts use scientific data to provide an adaptive framework wherein habitat and wildlife sustainability can co-exist with human activities. Good science informs decision-makers and facilitates the development of successful conservation approaches. However, conservation concerns for the dugong Dugong dugon in South-east Asia are sufficiently urgent that action must be taken quickly, even though science has not provided complete answers to critical questions. In Johor, Malaysia, aerial surveys were conducted to assess dugong numbers, dugong high-use areas and overlap of dugong sightings with areas of seagrass. Dugong distribution included existing marine parks and locations where known conservation threats exist. We conclude that the Johor islands may represent a significant congregation site for dugongs in Peninsular Malaysia, with as many as 20 dugongs recorded in a single day. The existence of a marine park where the dugong sightings were most prominent is encouraging but only $38 \%$ of those sightings fell within the boundaries of the park. Anthropogenic threats need to be assessed and addressed prior to complex development activities such as dredging and coastal reclamation for tourism development in this critical area. We use this case to explore the concept of advancing species conservation through focused research and management, particularly where uncertainties exist because data are scarce.
\end{abstract}

Keywords Conservation, Dugong dugon, Johor, Malaysia, protected area

\footnotetext{
LOUISA S. PONNAMPALAM* (Corresponding author) Institute of Ocean and Earth Sciences, Universiti Malaya, 50603 Kuala Lumpur, Malaysia

E-mail louisa.ponnampalam@gmail.com

J. H. FAIRUL IzMal The MareCet Research Organization, Shah Alam, Malaysia, and Environmental Resources Management, Kuala Lumpur, Malaysia

Kanjana Adulyanukosol Marine and Coastal Resources Research Center, Upper Gulf, Department of Marine and Coastal Resources, Samut Sakhon, Thailand

JiLLIAN L. S. OoI Department of Geography, Faculty of Arts and Social Sciences, Universiti Malaya, Kuala Lumpur, Malaysia

JoHn E. ReYNOLDS III Mote Marine Laboratory, Sarasota, Florida, USA

*Also at: The MareCet Research Organization, 40460 Shah Alam, Malaysia

Received 25 March 2013. Revision requested 15 July 2013.

Accepted 26 November 2013. First published online 8 July 2014.
}

This paper contains supplementary material that can be found online at http://journals.cambridge.org

\section{Introduction}

The dugong Dugong dugon (Sirenia, Dugongidae) has a I range spanning waters of 48 countries, from the tropical and subtropical shallow coastal habitats of East Africa to the Red Sea and Arabian Gulf, and eastwards to the Indo-Pacific region as far as Australia (Marsh, 2008). It is a seagrass-community specialist with a diet predominantly of seagrasses, occasionally consuming invertebrates and algae (Marsh et al., 2011). The dugong is categorized as Vulnerable on the IUCN Red List (Marsh, 2008), with some populations greatly diminished, threatened by human activities and in imminent danger of extirpation (Marsh et al., 2011). In South-east Asia studies of dugongs have assessed their relative abundance and threats to the species in Indonesia, Thailand, Cambodia, Vietnam and East Malaysia (de Iongh et al., 1998; de Iongh, 1999; Hines et al., 2005, 2008, 2012; Tsutsumi et al., 2006; Adulyanukosol et al., 2007; Jaaman et al., 2008, 2009; Rajamani \& Marsh, 2010; Rajamani, 2013).

In Peninsular Malaysia dugongs are protected under the Fisheries Act 1985 Part VI and the Fisheries (Control of Endangered Species of Fish) Regulations 1999. The Department of Fisheries formulated a National Plan of Action for Dugongs in 2011 to protect, conserve and manage dugongs and their habitats (DOFM, 2011). Additionally, Malaysia is committed to the Convention on Biological Diversity, with a target of having $10 \%$ of its marine environment protected by 2020, particularly areas that are important for threatened species (CBD, 2010). To date $<1 \%$ of Malaysia's marine area is protected (Bertzky et al., 2012). Seagrasses are protected only in areas where they fall within marine parks, and are not included in any national policies. Strandings of dugongs have been reported throughout Peninsular Malaysia since the 1940s (e.g. Gibson-Hill, 1950; Langham, 1974; Mansor et al., 2000) and the Department of Fisheries has maintained records of dugong mortality since the 1990s, particularly cases reported in the Johor Straits (DOFM, 2011). Nonetheless, information on the dugong in Peninsular Malaysian waters is incomplete but anecdotal evidence suggests that the species has become 


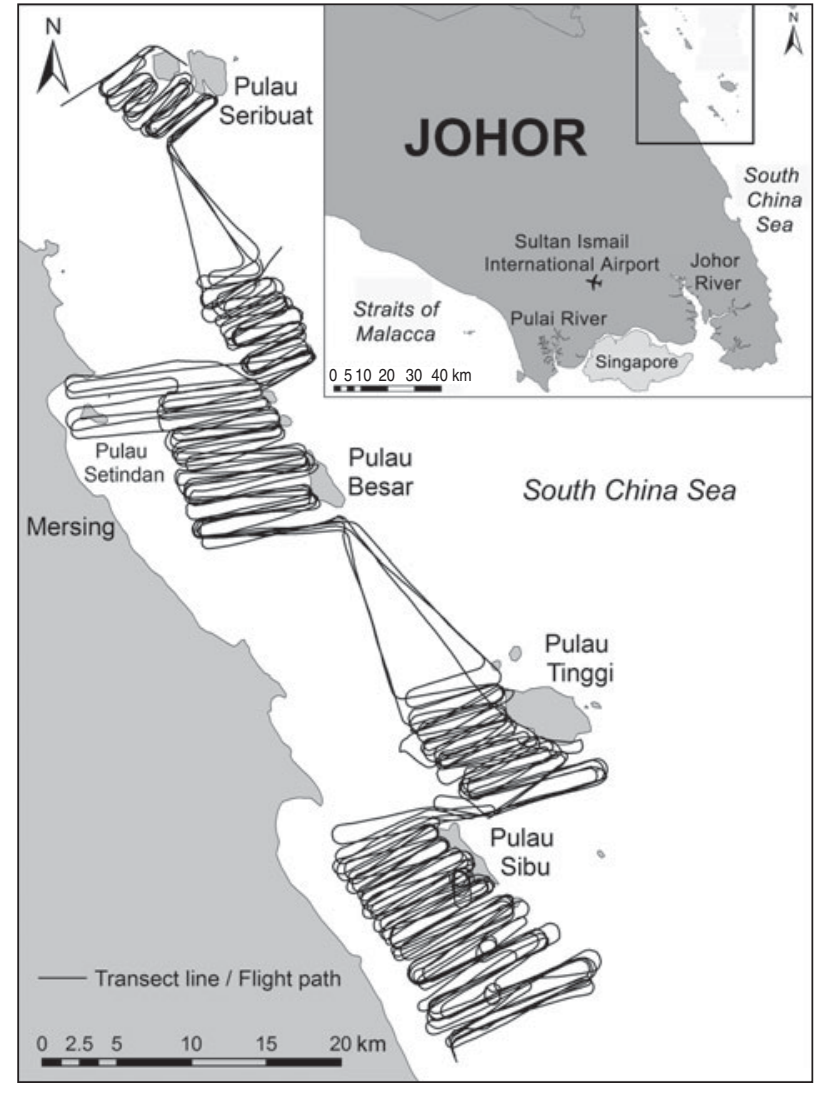

FIG. 1 The area surveyed for dugongs Dugong dugon around the islands off the east coast of Johor, and Pulau Seribuat (in the neighbouring state of Pahang). Parallel line transects were flown on the leeward sides of all islands, using a light aircraft. The rectangle on the inset shows the location of the main map off the coast of Peninsular Malaysia.

increasingly rare (Affendi et al., 2005; Zulkifli Poh, 2009; L.S. Ponnampalam, unpubl. data).

Beginning in 1999 several surveys were conducted to assess the distribution of dugongs around the Sungai Pulai and Sungai Johor estuaries (sungai $=$ river) and islands off the east coast of Johor (hereafter referred as the Johor islands; Fig. 1), as well as the distribution and diversity of seagrasses in these areas. Aerial surveys for dugongs and seagrass were conducted during 1999-2008 (Mansor et al., 2000; Affendi et al., 2005; Ooi et al., 2008) and studies of dugong feeding trails and community-based monitoring occurred during 2008-2009 (Zulkifli Poh, 2009; Choo \& Ponnampalam, 2011). Threats to dugongs and their habitats in Johor are varied and increasing in intensity (Ponnampalam \& Fairul Izmal, pers. obs.). Dugong carcasses have been reported from parts of Johor's coastline and found as bycatch in fishing gear (Affendi et al., 2005; Choo \& Ponnampalam, 2011; L.S. Ponnampalam, unpubl. data). Dugongs are already extirpated in Mauritius, the Maldives and Taiwan and are Critically Endangered in Okinawa, Japan, and in the Gulf of Mannar, between India and Sri Lanka (Marsh, 2008). Dugongs in Peninsular
Malaysia may also face eventual extirpation if their prime habitats remain unprotected, with no specific management measures implemented.

Here we present the results of a systematic aerial survey conducted around the Johor islands in July 2010. Our main objectives were to (1) determine the distribution of the dugong in the archipelago, (2) assess the encounter rate of dugongs, (3) compare dugong distribution with the extent of existing marine parks, seagrass habitat and areas with human activity, and (4) provide conservation and research recommendations. Our work illustrates how conservation efforts can commence using available data, existing laws and policy mechanisms when resources for research are limited.

\section{Methods}

Aerial surveys were conducted around the Johor islands and Pulau Seribuat (in the neighbouring state of Pahang; pulau $=$ island) for 8 consecutive days during $8-15$ July 2010 (Fig. 1). The surveys were conducted using a fixed-wing Cessna 172 aircraft, with two experienced observers on board, which departed from the Sultan Ismail International Airport in Senai, Johor. A series of predetermined parallel line transects, each c. 5-10 km in length and set c. $1 \mathrm{~km}$ apart, was designed for the survey (Fig. 1). The transects covered the leeward sides of each island and included areas where seagrass beds were known to occur (Affendi et al., 2005; Ooi et al., 2008, 2011b; J.L.S. Ooi, unpubl. data). Funding constraints prevented coverage of all of the regional inshore areas and repeated surveys.

Surveys were conducted during high tide each day, for consistency, at a search speed of $167 \mathrm{~km}$ per hour and altitude of $213 \mathrm{~m}$, in sea states $\leqslant 3$ on the Beaufort Scale. The first observer sat in the front right seat, next to the pilot, and the second observer sat in the back seat on the left.

The first observer photographed dugongs, using a digital single-lens reflex camera with a $75-300 \mathrm{~mm}$ zoom lens, and the survey search path was recorded using a global positioning system (GPS). Events that occurred during the flight (e.g. departure time, start of transect) were recorded using a digital voice-recorder. When an animal or vessel was sighted a waypoint was recorded on the GPS unit and the event recorded on the voice recorder, including information on group size, behaviour and the size of individuals (e.g. adult or calf). The flight was terminated when all transects had been completed or when weather and sighting conditions deteriorated (rain, haze, sea state $>$ Beaufort 3). Encounter rates were calculated by dividing the total number of individuals sighted during the whole survey by the total survey effort (days, distance, time). The distributions of animals and vessels were plotted in ArcMap v. 10.1 (ESRI, Redlands, USA) and overlaid on known seagrass 


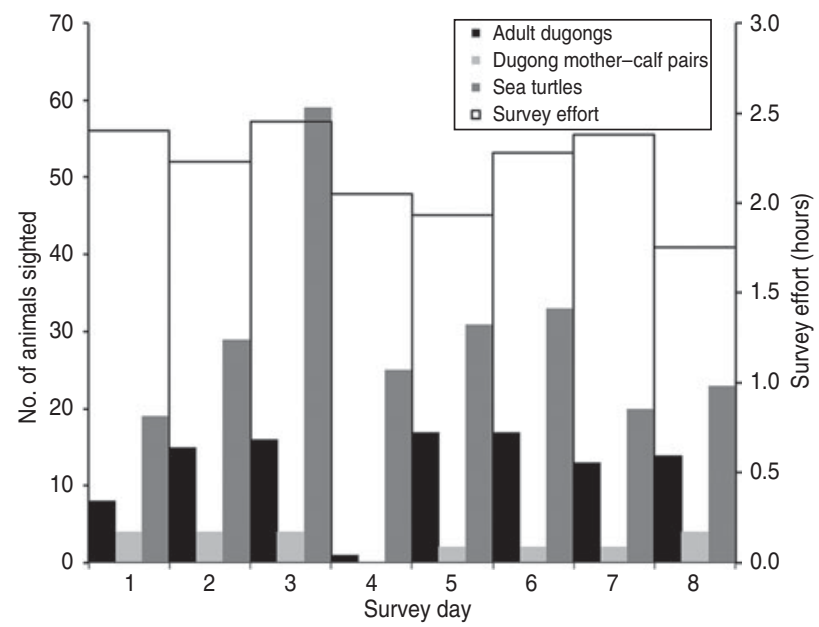

Fig. 2 Survey effort and number of sightings of adult dugongs, dugong mother-calf pairs and sea turtles per day during the aerial survey off the east coast of Johor, Malaysia (Fig. 1).

areas and existing marine park boundaries to assess the extent of overlap.

\section{Results}

The transects surveyed covered a total of $2,986.4 \mathrm{~km}$ of water, with 17.5 hours of observation. There were 93 sightings of dugongs, 22 of which consisted of mother-calf pairs. The maximum daily counts of dugongs and mothercalf pairs were 20 individuals and four pairs, respectively (Fig. 2). The largest group size observed was five and the smallest number was one. The daily mean encounter rates were 15.4 dugongs per day, 0.04 dugongs per $\mathrm{km}$ and 7.04 dugongs per hour.

Dugongs were sighted around all islands surveyed (Fig. 3a). The highest concentrations were observed around Pulau Sibu $(\mathrm{n}=66,71 \%)$ and Pulau Tinggi $(\mathrm{n}=15,16 \%$; combined total, $\mathrm{n}=81,87 \%$; Fig. $3 \mathrm{a}$ ). Of the total number of sightings around Pulau Sibu, 41 (62\%) were outside the boundary of the island's marine park. Sightings of mothercalf pairs ( $\mathrm{n}=19,21 \%$ ) were concentrated at Pulau Sibu and mainly outside its marine park boundary $(n=13,68 \%$; Fig. 3a). Two dugongs were sighted grazing in the seagrass beds at Pulau Setindan (Fig. 3a), near the site of the now-halted Mersing Laguna Reclamation development project.

A total of 178 sightings of green sea turtles Chelonia mydas were recorded during the surveys, concentrated over the extensive seagrass meadows of Pulau Sibu and Pulau Tinggi and extending beyond the boundary of Pulau Sibu marine park (Fig. 3b). Marine vessels observed were artisanal fishing boats with single outboard engines, fishing trawlers, high-speed ferries, cargo tankers and tugboats with barge (Fig. 3). These were sighted mainly around Pulau Sibu, Pulau Besar and Pulau Rawa. Artisanal fishing boats were observed most frequently (1.66 boats per hour), followed by fishing trawlers ( 0.97 boats per hour).

\section{Discussion}

\section{Dugongs, habitats and anthropogenic activities}

Our results suggest the dugong population in Johor is small, based on the maximum daily count of only 20 animals in $2,986.4 \mathrm{~km}$ of surveys. Conversely, few areas in South-east Asia have more dugongs in such a confined area (e.g. Trang Province, Thailand; Hines et al., 2005; Tsutsumi et al., 2006) and the high percentage of calves indicates a reproducing population. The highest concentrations of dugongs (including mother-calf pairs) and sea turtles, particularly off the south-west of Pulau Sibu, are attributable to the presence of seagrass meadows in the area. Ooi et al. (2011a) reported that the seagrasses Halodule uninervis and Cymodocea serrulata dominate the seagrass meadows in Pulau Tinggi and the dominant seagrass in the Pulau Sibu area is H. uninervis (Ooi et al., 2008). Both species are consumed extensively by dugongs (Marsh et al., 2011). Seagrass distribution data are lacking for the surveyed area, especially outside the Pulau Sibu marine park, where dugong sightings were concentrated, indicating the need for further surveys of seagrasses.

Of the three main dugong areas in Johor (i.e. Sungai Pulai and Sungai Johor estuaries and Johor islands; Fig. 1), the Johor islands appear to be the only area with habitat suitable for maintaining a viable population of dugongs. Our findings and those of Mansor et al. (2000) and Affendi et al. (2005) indicate that the Johor islands are the site of the most significant congregation of dugongs in Peninsular Malaysia. Previous seagrass surveys in the Sungai Pulai estuary (Zulkifli Poh, 2009; Choo \& Ponnampalam, 2011) and the Sungai Johor estuary (Affendi et al., 2005; Ooi et al., 2008) revealed the presence of dugong feeding trails in areas with high seagrass biomass. However, these areas are affected by major developments, including port expansions and petrochemical facilities, both of which are known to cause habitat degradation and water pollution and to threaten marine life (Ralph \& Burchett, 1998; Macinnis-Ng \& Ralph, 2003; Wake, 2005; Ng \& Song, 2010; Yap \& Lam, 2013). Thus, it is unlikely that these areas are sustainable long-term habitats for the dugongs. The Sungai Pulai estuary and the mangrove coastline of the Johor Straits are scheduled for significant development under the Iskandar Malaysia development plan (Iskandar Malaysia, 2011). The heavily industrialized Sungai Johor estuary area is also being developed further, to include a deep-water petroleum refinery (Integrated Envirotech, 2012). In interviews local fishermen from both areas reported low encounter rates with dugongs since 2004, with encounters mainly 


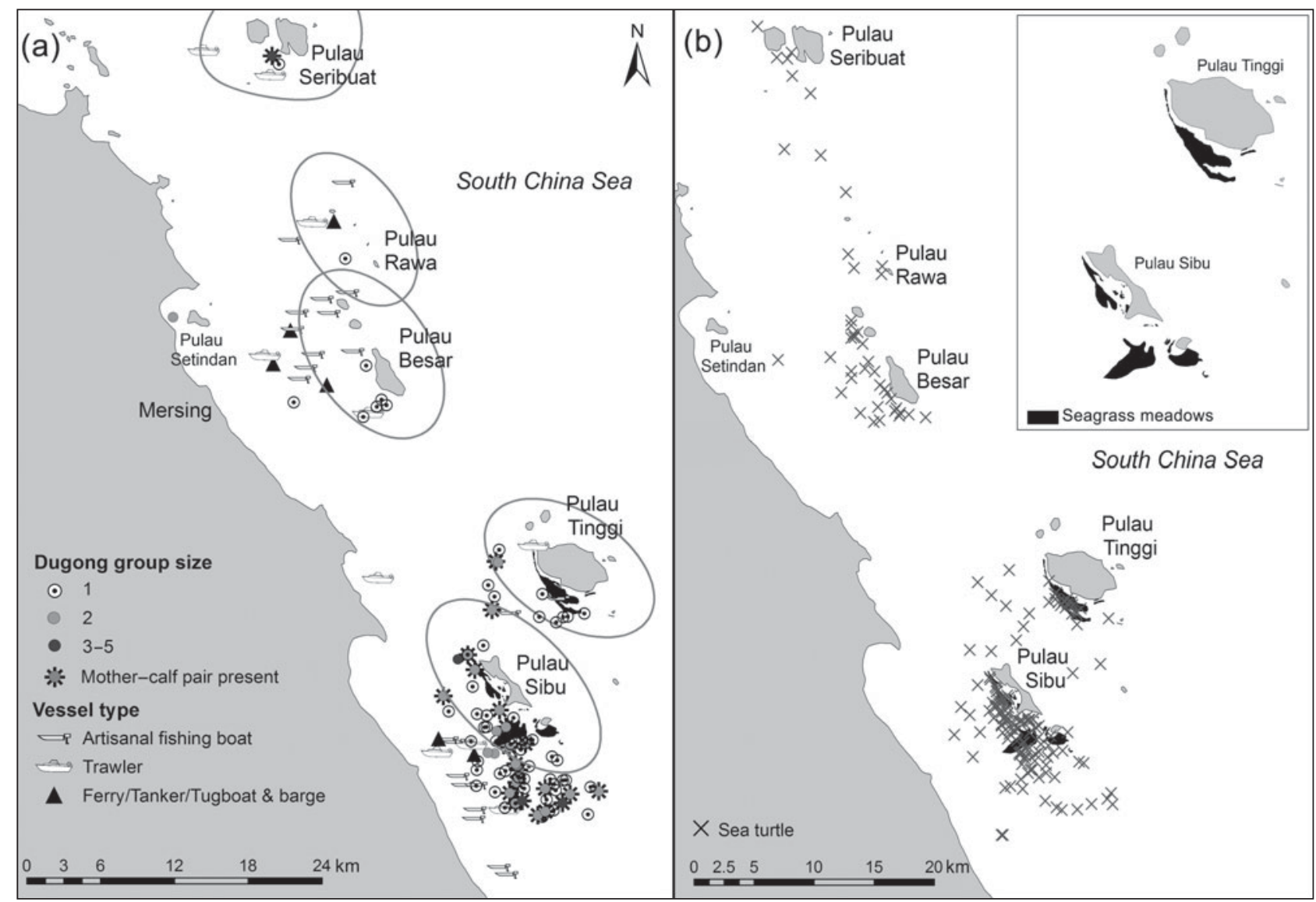

FIg. 3 (a) The locations of dugongs and marine vessels sighted during the aerial survey. The grey ovals around each island indicate the approximate boundaries of existing marine parks, which extend 2 nautical miles from the shoreline. (b) The locations of sea turtles sighted during the aerial survey. The inset in (b) shows the locations of known seagrass beds at Pulau Sibu and Pulau Tinggi (Affendi et al., 2005; Ooi et al., 2011b, unpubl. data).

involving stranded dead animals (Zulkifli Poh, 2009; L.S. Ponnampalam, unpubl. data).

In contrast, the Johor islands have experienced a lower level of human-induced environmental degradation, partly because of the designated marine parks in the area and the low levels of development on the islands (L.S. Ponnampalam, pers. obs.). Given the extensive areas of seagrass beds, particularly off Pulau Sibu and Pulau Tinggi, the islands are likely to be an important habitat for dugongs, providing them with safe refuge and an abundant food supply. However, interviews with fishermen along the east coast of Johor in 2010 revealed that commercial trawl fishing takes place illegally within the marine parks of Pulau Sibu and Pulau Tinggi (L.S. Ponnampalam, unpubl. data), which is likely to damage or destroy the dugongs' seagrass habitats (Duarte, 2009). Vessel traffic may also pose threats to dugongs in the study area, although our observations revealed some degree of separation between dugongs and vessels. The animals may be at risk from boat strikes and disturbance, which have already been demonstrated to be an increasing threat to dugongs in some heavily used waterways of Australia (Hodgson \& Marsh, 2007). Additionally, the vicinity of the Johor islands is exposed to the threats of large-scale coastal development projects, which include dredging and extensive land reclamation, under the East Coast Economic Region Master Plan. For example, the proposed (but cancelled) Mersing Laguna Reclamation in Mersing Bay was a potential threat to dugongs, the seagrass beds in the area and the general environment (Erftemeijer \& Lewis, 2006; Wang et al., 2010). Our survey results show that the proposed reclamation area may be a tide-influenced feeding ground for dugongs, as reported for dugongs in Australia (Sheppard et al., 2009). As such, increased protection of the area and specific management measures are needed to support dugong populations.

\section{Aligning conservation and research}

Lack of comprehensive scientific information should not be a deterrent to the implementation of conservation actions. We recommend that a dugong conservation area be designed and managed following the strategies outlined in Supplementary Table S1, combined with stakeholder 


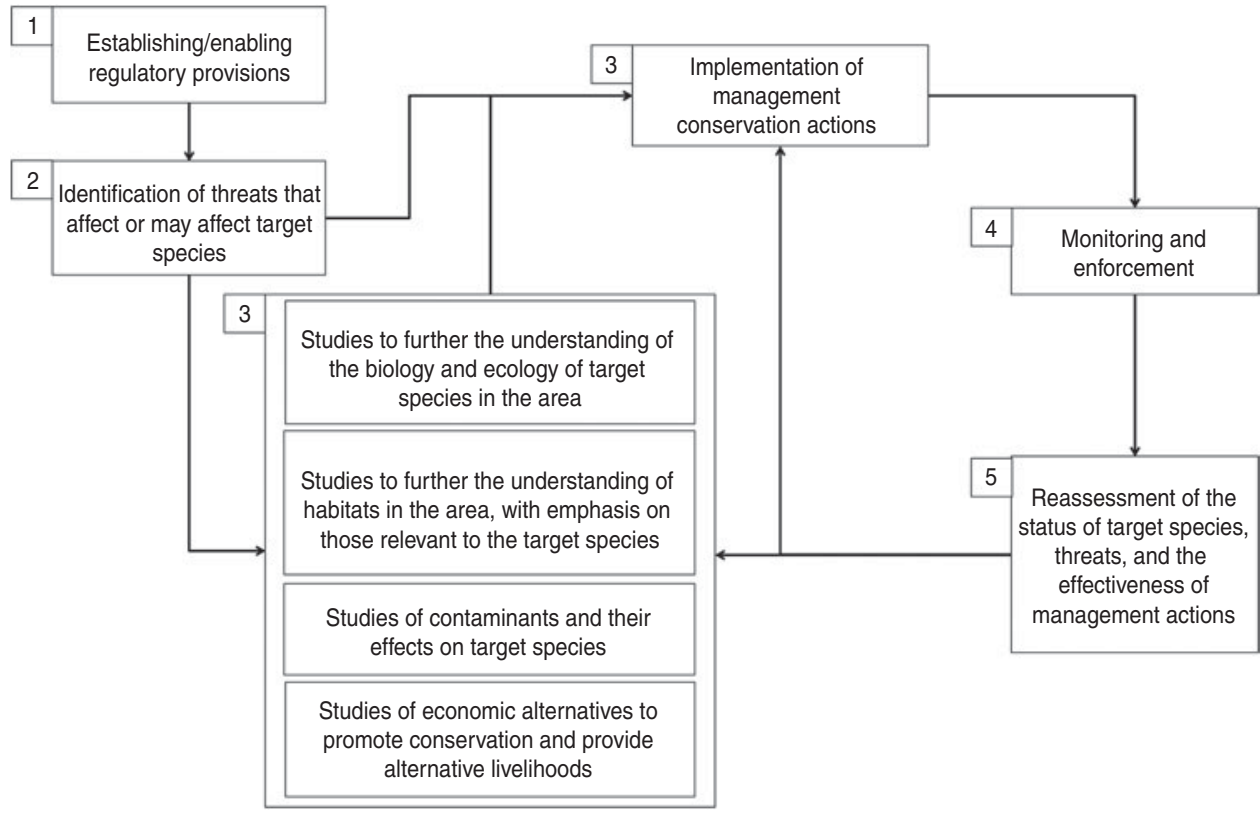

FIG. 4 Hierarchy of recommended actions for the conservation, management and research of dugongs and their habitats off the east coast of Johor, Peninsular Malaysia (Fig. 1). consultation and involvement. Furthermore, we recommend that focused research in priority areas (outlined in Supplementary Table S2) be undertaken in tandem with our conservation recommendations. Research and conservation should be undertaken concurrently, with each complementing the other, to continue to improve and strengthen the effectiveness of management of the area and target species over time (Fig. 4).

As a signatory to the Convention on Biological Diversity, Malaysia is obligated to protect $10 \%$ of representative marine ecosystems within its national boundaries. The establishment of a dugong conservation area would contribute to the global goal of meeting the Aichi Biodiversity Targets (CBD, 2010). Moreover, conservation alongside research is in line with the objectives and strategies of Malaysia's National Plan of Action for Dugongs (DOFM, 2011). We recommend that the dugong conservation area be established in the areas of high dugong concentrations, such as outside the boundaries of the existing Pulau Sibu marine park (Fig. 3). The protection afforded by the current marine parks alone is probably insufficient, as is the case in Indonesia (de Iongh, 1999), as anthropogenic activities continue to increase. We believe that, given the range of stakeholders and the fact that some of their activities may be benign to dugongs, a managed area that involves careful management of selected human activities is preferable to a marine park, which is fully protected under Malaysian law. Nonetheless, many social-cultural-economic aspects will need to be considered when establishing the dugong conservation area (Ban et al., 2009). A framework for conservation of sirenians is provided in Marsh et al. (2011) and Hines et al. (2012), encompassing a range of regulatory (e.g. legislation, enforcement and protected areas) and enabling tools (e.g. education/awareness-raising, research and adaptive management, community partnerships). The careful development, implementation and maintenance of a combination of both categories of tools are critical to the conservation of dugongs in Malaysia and elsewhere. Although there have been discussions among stakeholders since this research was carried out, the rate of progress towards establishing a managed area is slow. In 2013 the protected area boundaries were extended by 1 nautical mile under state legislation, which, while useful, does not fully encompass the areas identified to be of significance to the dugong population at the study site.

The waters around the Johor islands potentially host the most significant concentration of dugongs in Peninsular Malaysia, partly as a result of the protection provided by marine parks, which are located away from development. Despite the low counts from our survey the presence of calves, substantial areas of forage, and marine parks provide hope that the dugongs can be conserved through proactive actions. We suggest that limited data, in this case on dugong distribution, extent of seagrass habitat and the use of such habitat by dugongs, are not a barrier to effective and enhanced conservation actions, especially where marine parks and statutory protection already exist. We emphasize that conservation and adaptive management actions should be implemented immediately in some cases while collection of scientific data continues. Multi-disciplinary research activities are being undertaken to improve understanding of the distribution and habitat use of dugongs, and the federal and Johor state governments have taken an interest in the matter. However, the level of threat to the dugong population in the area is likely to increase (Ponnampalam \& Fairul Izmal, pers obs.). 
The case of the dugongs in the Johor islands suggests that for certain wildlife species or populations there may be insufficient time to wait for comprehensive scientific justification and data collection before conservation actions are implemented (Johannes, 1998). In most cases involving threatened species, research should be undertaken concurrently with conservation actions (Marsh et al., 2011).

\section{Acknowledgements}

Funding for this survey was provided by Titan Chemical Corp. Bhd. We thank our pilot, Capt. Cheng Xitao, for his contribution, and Vivian Kuit for assisting with editing of the figures.

\section{References}

Adulyanukosol, K., Hines, E. \& Boonyanate, P. (2010) Cultural significance of dugong to Thai villagers: implications for conservation. Proceedings of the 5 th International Symposium of SEASTAR20oo and Asian Bio-logging Science (The 9th SEASTAR2ooo workshop), 43-49.

Adulyanukosol, K., Thongsukdee, S., Hara, T., Arai, N. \& Tsuchiya, M. (2007) Observations of dugong reproductive behavior in Trang Province, Thailand: further evidence of intraspecific variation in dugong behavior. Marine Biology, 151, 1887-1891.

Affendi, Y.A., Ooi, J.L.S., Phang, S.M., Hussin, A., Rosman, F.R. \& FAUZI, R. (2005) Dugongs in Peril: The Conservation and Protection of Dugongs in Johor, Malaysia. Report to the United Nations Development Programme (UNDP), Kuala Lumpur, Malaysia.

Ban, N.C., Hansen, G.J.A., Jones, M. \& Vincent, A.C.J. (2009) Systematic marine conservation planning in data-poor regions: socioeconomic data is essential. Marine Policy, 33, 794-800.

Bertzky, B., Corrigan, C., Kemsey, J., Kenney, S., Ravilious, C. Besancon, C. \& Burgess, N. (2012) Protected Planet Report 2012: Tracking Progress Towards Global Targets for Protected Areas. IUCN, Gland, Switzerland, and UNEP-WCMC, Cambridge, UK.

Calleson, C.S. \& Frohlich, R.K. (2007) Slower boat speeds reduce risks to manatees. Endangered Species Research, 3, 295-304.

(CBD) (Convention on Biological Diversity) (2010) Decision X/2, Strategic Plan for Biodiversity 2011-2020, including Aichi Biodiversity Targets. Https://www.cbd.int/sp/ [accessed 31 August 2013].

Choo, C.K. \& Ponnampalam, L.S. (2011) Empowering Coastal Communities for Marine Biodiversity Management at the Pulai River Estuary. Project MAL/SGP/OP4/Y1/RAF/2008/FP-09(53) Final Report to the GEF-SGP. Malaysian Society of Marine Sciences, Selangor, Malaysia.

Danielsen, F., Balete, D.S., Poulsen, M.K., Enghoff, M., Nozawa, C.M. \& Jensen, A.E. (2000) A simple system for monitoring biodiversity in protected areas of a developing country. Biodiversity and Conservation, 9, 1671-1705.

DE IONGH, H. (1999) Optimizing the design of marine reserves to protect dugongs in a small island ecosystem. Tigerpaper, 26, 6-13. De Iongh, H.H., Langeveld, P. \& van der Wal, M. (1998) Movement and home ranges of dugongs around the Lease Islands, East Indonesia. Marine Ecology, 19, 179-193.
DOFM (Department of Fisheries Malaysia) (2011) National Plan of Action for Dugongs. DOFM, Putrajaya, Malaysia. [In Bahasa Malaysia]

Duarte, C. (2002) The future of seagrass meadows. Environmental Conservation, 29, 192-206.

DuArte, C. (ed.) (2009) Global Loss of Coastal Habitats: Rates, Causes and Consequences. Fundación BBVA, Bilbao, Spain.

Erftemeijer, P.L.A. \& Lewis, R.R.R. (2006) Environmental impacts of dredging on seagrasses: a review. Marine Pollution Bulletin, 52, 1553-1572.

Fisher, B., Bateman, I. \& Turner, R.K. (2011) Valuing ecosystem services: benefits, values, space and time. Ecosystems Services Economics (ESE) Working Paper Series, 3. United Nations Environment Programme.

GerRARD, C. (1999) Dugong-watching tourism and encounter response of the dugong (Dugong dugon) in Shark Bay, Western Australia. MSc thesis. University of Calgary, Alberta, Canada.

Gibson-Hill, C.A. (1950) The dugong. Malayan Nature Journal, 5, 25-29.

Guerry, A. (2005) Icarus and Daedalus: conceptual and tactical lessons for marine ecosystem-based management. Frontiers in Ecology and the Environment, 3, 202-211.

Hines, E.M., Adulyanukosol, K. \& Duffus, D.A. (2005) Dugong (Dugong dugon) abundance along the Andaman coast of Thailand. Marine Mammal Science, 21, 536-549.

Hines, E., Adulyanukosol, K., Somany, P., Leng, S.A., Cox, N., Boonyanate, P. \& NGuyen, X.H. (2008) Conservation needs of the dugong Dugong dugon in Cambodia and Phu Quoc Island, Vietnam. Oryx, 42, 113-121.

Hines, E., Reynolds, J.E. III, Mignucci-Giannoni, A.A., Aragones, L.V. \& Marmontel, M. (eds) (2012) Sirenian Conservation: Issues and Strategies in Developing Countries. University Press of Florida, Gainesville, USA.

Hodgson, A.J. \& Marsh, H. (2007) Response of dugongs to boat traffic: the risk of disturbance and displacement. Journal of Experimental Marine Biology and Ecology, 340, 50-61.

Integrated Envirotech (2012) Detailed Environmental Impact Assessment (DEIA) for Refinery and Petrochemical Integrated Development (RAPID) in Pengerang, Johor. Report prepared for Petroliam Nasional Berhad, Kuala Lumpur, Malaysia.

Iskandar Malaysia (2011) Five Year Progress Report. Http://www. iskandarmalaysia.com.my/pdf/five-year-progress-report.pdf [accessed 15 September 2013].

Jaaman, S.A., Lah-Anyi, Y.U. \& Pierce, G.J. (2008) Directed fisheries for dolphins and dugongs in Sabah, East Malaysia: past and present. Borneo Science, 23, 1-20.

Jahman, S.A., Lah-Anyi, Y.U. \& Pierce, G.J. (2009) The magnitude and sustainability of marine mammal by-catch in fisheries in East Malaysia. Journal of the Marine Biological Association of the United Kingdom, 89, 907-920.

Johannes, R.E. (1998) The case for data-less marine resource management: examples from tropical nearshore finfisheries. Trends in Ecology \& Evolution, 13, 243-246.

Kiszka, J., Ersts, P.J. \& Ridoux, V. (2007) Cetacean diversity around the Mozambique Channel Island of Mayotte (Comoros archipelago). Journal of Cetacean Research and Management, 9, 105-109.

Langham, N. (1974) Dugongs in Malaysian waters. Malayan Nature Journal, 28, 35.

Lanyon, J.M., Johns, T. \& Sneath, H.L. (2005) Year-round presence of dugongs in Pumicestone Passage, south-east Queensland, examined in relation to water temperature and seagrass distribution. Wildlife Research, 32, 361-368. 
Macinnis-NG, C.M.O. \& RalPh, P.J. (2003) In situ impact of petrochemicals on the photosynthesis of the seagrass Zostera capricorni. Marine Pollution Bulletin, 46, 1395-1407.

Mansor, M.L., Ahmad, A., Kushairi, M.R.M. \& Marsh, H. (2000) Dugongs in Peninsular Malaysia. FRI News, 5, 18.

Marsh, H. (2008) Dugong dugon. In IUCN Red List of Threatened Species v. 2012.2. Http://www.iucnredlist.org [accessed 10 November 2012].

Marsh, H., O'Shea, T.J. \& Reynolds, J.E. III (2011) Ecology and Conservation of the Sirenia-Dugongs and Manatees. Cambridge University Press, New York, USA.

McLachlan, M.S., Haynes, D. \& Müller, J.F. (2001) PCDDs in the water/sediment-seagrass-dugong (Dugong dugon) food chain on the Great Barrier Reef (Australia). Environmental Pollution, 113, 129-134.

Mellors, J.E., McKenzie, L.J. \& Coles, R.G. (2008) Seagrass-Watch: engaging Torres Strait islanders in marine habitat monitoring. Continental Shelf Research, 28, 2339-2349.

$\mathrm{N}_{\text {G }}$, A.K.Y. \& SoNG, S. (2010) The environmental impacts of pollutants generated by routine shipping operations on ports. Ocean \& Coastal Management, 53, 301-311.

Northridge, S.P. \& Hofman, R.J. (1999) Marine mammal interactions with fisheries. In Conservation and Management of Marine Mammals (eds J.R. Twiss, R. Reeves \& S. Montgomery), pp. 99-119. Smithsonian Institution Press, Washington, DC, USA.

Ooi, J.L.S., Affendi, Y.A. \& Phang, S.M. (2008) PHASE II Dugongs in Peril: The Conservation and Protection of Dugongs in Johor, Malaysia. Part I: Seagrass Survey Report July 2008. Report to Titan Chemical Corp. Bhd, Pasir Gudang, Malaysia.

Ooi, J.L.S., Kendrick, G.A. \& VAN Niel, K.P. (2011a) Effects of sediment burial on tropical ruderal seagrasses are moderated by clonal integration. Continental Shelf Research, 31, 1945-1954.

Ooi, J.L.S., Kendrick, G.A., Van Niel, K.P. \& Affendi, Y.A. (2011b) Knowledge gaps in tropical Southeast Asian seagrass systems. Estuarine, Coastal and Shelf Science, 92, 118-131.

Pratt, D.G., Macmillan, D.C. \& Gordon, I.J. (2004) Local community attitudes to wildlife utilization in the changing economic and social context of Mongolia. Biodiversity and Conservation, 13, 591-613.

RAJAMANI, L. (2013) Using community knowledge in data-deficient regions: conserving the Vulnerable dugong Dugong dugon in the Sulu Sea, Malaysia. Oryx, 47, 173-176.

Rajamani, L. \& MARSh, H. (2010) Using parallel regional- and localscale initiatives to inform conservation management of rare wildlife: a case study of the dugong Dugong dugon in Sabah, Malaysia. Endangered Species Research, 13, 17-23.

Ralph, P.J. \& BurChetT, M.D. (1998) Impact of petrochemicals on the photosynthesis of Halophila ovalis using chlorophyll fluorescence. Marine Pollution Bulletin, 36, 429-436.

Sheppard, J.K., Jones, R.E., Marsh, H. \& Lawler, I.R. (2009) Effects of tidal and diel cycles on dugong habitat use. Journal of Wildlife Management, 73, 45-59.
Tallis, H. \& Polasky, S. (2009) Mapping and valuing ecosystem services as an approach for conservation and natural-resource management. Annals of the New York Academy of Sciences, 1162, 265-283.

TIKEL, D. (1997) Using a genetic approach to optimise dugong (Dugong dugon) conservation management. $\mathrm{PhD}$ thesis. James Cook University, Townsville, Australia.

Tsutsumi, C., Ichikawa, K., Arai, N., Akamatsu, T., Shinke, T., Hara, T. \& Adulyanukosol, K. (2006) Feeding behavior of wild dugongs monitored by a passive acoustical method. Journal of the Acoustical Society of America, 120, 1356-1360.

Vetter, W., Scholz, E., Gaus, C., Mưller, J.F. \& Haynes, D. (2001) Anthropogenic and natural organohalogen compounds in blubber of dolphins and dugongs (Dugong dugon) from northeastern Australia. Archives of Environmental Contamination and Toxicology, 41, 221-231.

WAKE, H. (2005) Oil refineries: a review of their ecological impacts on the aquatic environment. Estuarine, Coastal and Shelf Science, 62, 131-140.

Wang, X., Chen, W., Zhang, L., Jin, D. \& Lu, C. (2010) Estimating the ecosystem service losses from proposed land reclamation projects: a case study in Xiamen. Ecological Economics, 69 2549-2556.

Wetzel, D.L., Pulster, E. \& Reynolds, J.E. III (2012) Organic contaminants and sirenians. In Sirenian Conservation: Issues and Strategies in Developing Countries (eds E. Hines, J.E. Reynolds III, A.A. Mignucci-Giannoni, L.V. Aragones \& M. Marmontel), pp. 196-203. University Press of Florida, Gainesville, USA.

YAP, W.Y. \& LAM, J.S.L. (2013) 80 million-twenty-foot-equivalent-unit container port? Sustainability issues in port and coastal development. Ocean \& Coastal Management, 71, 13-25.

Zulkifli PoH, A.N. (2009) Dugong feeding patterns and food preferences in Sg. Pulai, Johor. BSc thesis. Universiti Malaysia Terengganu, Terengganu, Malaysia.

\section{Biographical sketches}

Louisa Ponnampalam is working towards filling the knowledge gaps on the ecology of dugongs and cetaceans in Malaysia and building local research capacity for conservation. FAIRUL IZMAL is a marine environmental consultant. His interests lie in improving scientific knowledge, awareness and policy legislation in relation to cetaceans and dugongs in Malaysia. KANJANa AdUlyanukosol has studied dugongs in Thailand for 25 years and has been involved in community education in her study areas. JILLIAN OoI studies the distribution patterns of tropical seagrasses in relation to ecological drivers, and the utilization of seagrass habitats by marine organisms. JOHN E. REYNOLDS III has been involved in conservation-based marine mammal research and global marine conservation efforts over the last 4 decades. 